\title{
Role of thyroid function tests in women with abnormal uterine bleeding
}

\author{
Mangala Gowri, B. H. Radhika*, Harshini V, Renuka Ramaiaha
}

Department of Obstetrics and Gynecology, ESIC-MC PGIMSR, Bangalore - 560010, Karnataka, India

Received: 10 November 2013

Accepted: 9 December 2013

*Correspondence:

Dr. B. H. Radhika

Email: radsgowda85@gmail.com

(C) 2014 Gowri $\mathrm{M}$ et al. This is an open-access article distributed under the terms of the Creative Commons Attribution Non-Commercial License, which permits unrestricted non-commercial use, distribution, and reproduction in any medium, provided the original work is properly cited.

\begin{abstract}
Background: A relationship between the thyroid gland and the gonads is suggested by the far more frequent occurrence of thyroid disorders in women than in men and by the common appearance of goiter during puberty, pregnancy and the menopause. Both hypothyroidism and hyperthyroidism may result in menstrual disturbances. Objective of current study is to study and correlate the thyroid function tests in women with abnormal uterine bleeding.

Methods: After selecting the women, informed consent was obtained. The case history and clinical examination of them were done, requested to do thyroid functioning test in fasting status in early morning and the results were evaluated. Other required investigations as per requirement were done and the patients were managed accordingly. The thyroid function tests were done by radioimmuno assays in the lab.

Results: There were 170 women who were included in the study. Out of all the types of menstrual irregularities, $50 \%$ (85) presented with oligomenorrhoea. We found that 132 women had normal thyroid status while 30 women had hypothyroidism out of them, 5 had subclinical hypothyroidism. Eight women had hyperthyroidism.

Conclusions: As there is high incidence of thyroid diseases in our area, women with abnormal uterine bleeding are to be screened. This would also avoid unnecessary hormonal treatment and surgery in these patients.
\end{abstract}

Keywords: Abnormal uterine bleeding, Menorrhagia, Oligomenorrhoea, Hypothyroidism, Hyperthyroidism

\section{INTRODUCTION}

A relationship between the thyroid gland and the gonads is suggested by the far more frequent occurrence of thyroid disorders in women than in men and by the common appearance of goiter during puberty, pregnancy and the menopause. ${ }^{1}$ While activity of the thyroid is closely linked with the process of ovarian maturation, the thyroid gland is itself dependent on direct and indirect stimuli from the ovary to discharge its own function. ${ }^{2}$

It is recognized universally that menstrual disturbances may accompany and even may precede thyroid dysfunction .In the present study thyroid status of patients presenting with abnormal uterine bleeding was assessed by TSH, T3, and T4 assay. Both hypothyroidism and hyperthyroidism may result in menstrual disturbances.
Hyperthyroidism reduces menstruation and hypothyroidism causes menorrhagia. Hyperthyroidism in contrast is associated with a menorrhagia and oligomenorrhoea and the decrease in flow is proportional to the severity of the thyrotoxicosis. ${ }^{3}$

The menstrual pattern is influenced by thyroid hormones directly through impact on the ovaries and indirectly through impact on SHBG, PRL and GnRH secretion and coagulation factors. Severe hypothyroidism is commonly associated with ovulatory dysfunction due to numerous interactions of thyroid hormones with the female reproductive system. Both hyperprolactinaemia, due to increased TRH production, and altered GnRH pulsatile secretion, leading to a delay in $\mathrm{LH}$ response and inadequate corpus luteum, have been reported. ${ }^{4-6}$ Thyroid responsivity by the ovaries could be explained by the 
presence of thyroid hormone receptors in human oocytes. $^{7}$ Thyroid hormones also synergize with the FSHmediated $\mathrm{LH} / \mathrm{hCG}$ receptor to exert direct stimulatory effects on granulosa cell function (progesterone production), ${ }^{8}$ and in in vitro studies effects on differentiation of the trophoblast have been shown. ${ }^{9}$ Another pathway through which hypothyroidism may impact on fertility is by altering the peripheral metabolism of oestrogen and by decreasing SHBG production. Both pathways may result in an abnormal feedback at the pituitary level. Independently of hormonal changes, hypothyroidism can also lead to menorrhagia by altered production of coagulation factors (decreased levels of factors VII, VIII, IX and XI). ${ }^{10}$

Subclinical hypothyroidism (SCH) has recently been challenged as data have indicated that physiological free $\mathrm{T}_{4}\left(\mathrm{FT}_{4}\right)$ variations are narrower in one individual than those observed within the reference range of a population. These data might reflect an abnormally low $\mathrm{FT}_{4}$ value for patients who present a mildly increased serum TSH. ${ }^{11,12}$ Some authors have proposed restricting the upper normality limit of serum TSH to $2.5 \mathrm{mU} / \mathrm{l}$. Today, however, there is no agreement among endocrinologists about the most appropriate (i.e. physiologically relevant) upper limit of normality for serum TSH. ${ }^{13}$

Recently "occult" menorrhagia has been found to be an early manifestation of sub clinical hypothyroidism with disease becoming symptomatic later. ${ }^{2}$ SHBG production increases in hyperthyroid women, the metabolism of oestrogen is altered and the conversion of androgens to oestrogens is increased. Hyperthyroxinemia increases the gonadotrophin response to $\mathrm{GnRH}$ and baseline gonadotrophin concentrations are also frequently elevated. The decrease in menstrual flow may also relate to effects on haemostatic factors, including the synthesis of factor VIII. ${ }^{14}$ Despite these metabolic changes, hyperthyroid women usually maintain ovulation, according to endometrial biopsies. ${ }^{15}$

Treating thyroid dysfunction can reverse menstrual abnormalities and thus improve fertility. A close interplay between thyroid hormones and normal steroid action and secretion exists, necessary for normal ovarian function and thus fertility. Women with thyroid dysfunction often have menstrual irregularities, infertility and increased morbidity during pregnancy. ${ }^{16}$

\section{Objective}

To study and correlate the thyroid function tests in women with abnormal uterine bleeding.

\section{METHODS}

Inclusion criteria: Women with abnormal uterine bleeding belonging to age group 15-45 years. Exclusion criteria: Pregnant women.
After selecting the women, informed consent was obtained. The case history and clinical examination of them were done, requested to do thyroid functioning test in fasting status in early morning and the results were evaluated. Other required investigations as per requirement were done and the patients were managed accordingly. The thyroid function tests were done by radioimmuno assays in the lab.

The study protocol included: 1) Detailed history taking with emphasis on age, parity, infertility and menstrual disorders. 2) Evaluation by pelvic examination along with general physical examination of those with menstrual complaints. 3) Routine investigations like $\mathrm{Hb}, \mathrm{BT}, \mathrm{CT}$, TLC, DLC, Platelet count and ABO-Rh in all. 4) Special investigations: (i) Transabdominal USG: (ii) Endometrial biopsy.

\section{RESULTS}

There were 170 women who were included in the study. The age groups of all the patients are mentioned in Table 1. Out of all the types of menstrual irregularities, 50\% [85] presented with oligomenorrhoea, 45 [26.4\%] had menorrhagia. 22 women had polymenorrhoea, out of them 10 were diagnosed to have hypothyroidism. 5 of 7 women with hypomenorrhoea had hypothyroidism. 9 women had presented with menstrual irregularities and infertility. In our study, thyroid levels in the serum were measured during early morning [fasting state], we found that 132 women had normal thyroid status while 30 women had hypothyroidism out of them, 5 had subclinical hypothyroidism. 8 women had hyperthyroidism.

Table 1: Age distribution of the patients.

\begin{tabular}{|ll|}
\hline $\begin{array}{l}\text { Age in } \\
\text { years }\end{array}$ & $\begin{array}{l}\text { Number of } \\
\text { patients }\end{array}$ \\
\hline $15-19$ & 17 \\
\hline $20-25$ & 36 \\
\hline $26-30$ & 38 \\
\hline $31-35$ & 28 \\
\hline $36-40$ & 26 \\
\hline $41-45$ & 25 \\
\hline Total & 170 \\
\hline
\end{tabular}

Table 2: Thyroid profile of the patients.

\begin{tabular}{|llll|}
\hline Thyroid levels & $\mathrm{T}_{3}$ & $\mathrm{~T}_{4}$ & $\mathrm{TSH}$ \\
\hline Normal & 132 & $132[77.6 \%]$ & $132[77.6 \%]$ \\
\hline Increased & 17 & $17[10 \%]$ & $30[17.6 \%]$ \\
\hline Decreased & 21 & $21[12.3 \%]$ & $8[5.5 \%]$ \\
\hline
\end{tabular}


Table 3: Other diagnosis of the patients.

\begin{tabular}{|ll|}
\hline Other diagnosis & $\begin{array}{l}\text { Number of } \\
\text { patients }\end{array}$ \\
\hline Endometrial hyperplasia & 7 \\
\hline PCOS & $22[12.9 \%]$ \\
\hline Ovarian cyst & $3[1.7 \%]$ \\
\hline Fibroid uterus & $6[2.4 \%]$ \\
\hline Hyperprolactinemia & $3[1.7 \%]$ \\
\hline Goiter & 2 \\
\hline
\end{tabular}

Table 4: Parity distribution of patients.

\begin{tabular}{|ll|}
\hline Parity & $\begin{array}{l}\text { Number of } \\
\text { women }\end{array}$ \\
\hline Unmarried & 16 \\
\hline Nulliparous & 34 \\
\hline Primipara & 30 \\
\hline Para 2 & 67 \\
\hline$>$ Para 2 & 23 \\
\hline Total & 170 \\
\hline
\end{tabular}

\section{DISCUSSION}

Thyroid disorders are more common in women with menstrual irregularities as compared to general population. The prevalence of hypothyroidism in women in the reproductive age (20-40 years) varies between $2 \%$ and $4 \%$. In the general population, the prevalence of subclinical hyperthyroidism is approximately $1.5 \% .{ }^{17}$ In the present study, $17.6 \%$ of women were hypothyroid, $2.7 \% \%$ had sub clinical hypothyroidism and $4.7 \%$ had hyperthyroidism. Joshi et al. found $68 \%$ of menstrual abnormalities in 22 women with hypothyroidism compared to only $12 \%$ in 49 controls. ${ }^{18}$ In the study by Krassas et al., the prevalence of menstrual irregularities (mainly oligomenorrhoea) reached 23\% among 171 hypothyroid patients, while being only $8 \%$ in 214 controls $(P<0.05)$. There were also $12 \%$ of women presenting with amenorrhoea in the hypothyroid group, and none among the control subjects. ${ }^{19}$ The most common menstrual irregularity in our study was oligomenorrhoea followed by menorrhagia.

Women with hyperprolactinemia also had thyroid dysfunction in our study. There were women with PCOS, infertility and 3 of them were diagnosed to have hypothyroidism in this study. Among women with abnormal uterine bleeding, the other disorders diagnosed in our study 6 had fibroid uterus, 7 had endometrial hyperplasia, 3 with ovarian cyst and were managed accordingly. 3 women had history of early pregnancy loss, 2 women had history of post partum depression and now developed thyroid dysfunction i.e., hypothyroidism and are on treatment.

Women with history of early pregnancy loss, recurrent miscarriages, postpartum depression, women with sub clinical hypothyroidism, infertility, associated with menstrual irregularities are all to be screened for thyroid dysfunction. Targeted screening at regular intervals should be recommended. This should also be considered in women who have had gynaecological and/or obstetric complications associated with hypothyroidism and in whom treatment is shown to be beneficial. Thus, screening selected patient groups is probably justified, based on the significant risks to offspring, the probable benefit of treatment, and the probable low incidence of adverse outcomes from intervention.

\section{CONCLUSIONS}

As there is high incidence of thyroid diseases in our area, women with abnormal uterine bleeding are to be screened. This would also avoid unnecessary hormonal treatment and surgery in these patients.

Further studies with more number of patients are required to evaluate the role of targeted screening at regular intervals for women with history of obstetric complications and infertility who have more risk of developing thyroid dysfunction.

\section{AKNOLWEDGEMENTS}

We thank all the women who took part in our study. We also thank our department and also biochemistry department for their support without which this study could not have been possible.

Funding: No funding sources

Conflict of interest: None declared

Ethical approval: The study was approved by the institutional ethics committee

\section{REFERENCES}

1. Cunningham $\mathrm{F}$ G, Gant $\mathrm{N}$ F, Leveno $\mathrm{K} J$ et al. William's Obst. $21^{\text {st }}$ Ed. New York, NY: McGraw Hill; 2001:1344.

2. Neelu Sharma, Anita Sharma. Thyroid Profile in Menstrual Disorders. JK Science. 2012JanuaryMarch;14(1):14-7.

3. Kaur T, Aseeja V, Sharma S. Thyroid Dysfunction in Dysfunctional Uterine Bleeding. Webmed Central Obstetrics and Gynaecology. 2011;2(9):WMC002235.

4. Longcope C., Abend S., Braverman, L.E. \& Emerson C.H. Androstenedione and estrone dynamics in hypothyroid women. Journal of Clinical Endocrinology and Metabolism. 1990;70:903-7.

5. Scanlon M.F., Chan V., Heath M., Pourmand M., Rodriguez-Arnao M.D., Weightman D.R., Lewis M. \& Hall R. Dopaminergic control of thyrotropin, alpha-subunit, thyrotropin beta-subunit, and prolactin in euthyroidism and hypothyroidism: dissociated responses to dopamine receptor blockade with metoclopramide in hypothyroid subjects. Journal of 
Clinical Endocrinology and Metabolism. 1981;53:360-5.

6. Thomas R. \& Reid R.L. Thyroid disease and reproductive dysfunction: a review. Obstetrics and Gynecology. 1987;70:789-98.

7. Wakim A.N. Polizotto, S.L., Buffo M.J., Marrero M.A. \& Burholt D.R. Thyroid hormones in human follicular fluid and thyroid hormone receptors in human granulosa cells. Fertility and Sterility. 1993;59:1187-90.

8. Cecconi S., Rucci N., Scaldaferri M.L., Masciulli M.P., Rossi G., Moretti C., D’Armiento M. \& Ulisse S. Thyroid hormone effects on mouse oocyte maturation and granulosa cell aromatase activity. Endocrinology. 1999;140:1783-8.

9. Maruo T., Matsuo H. \& Mochizuki M. Thyroid hormone as a biological amplifier of differentiated trophoblast function in early pregnancy. Acta Endocrinologica. 1991;125:58-66.

10. Ansell J.E. The blood in the hypothyroidism. In: L. Braverman, R. Utiger eds. Werner and Ingbar's the Thyroid: A Fundamental and Clinical Text. 7th ed. Philadelphia: Lippincott-Raven; 1996: 821-825.

11. Andersen S., Pedersen K.M., Bruun N.H. \& Laurberg P. Narrow individual variations in serum $\mathrm{T}(4)$ and $\mathrm{T}(3)$ in normal subjects: a clue to the understanding of subclinical thyroid disease. Journal of Clinical Endocrinology and Metabolism. 2002;87:1068-72.

12. Baloch Z., Carayon P., Conte-Devolx B., Demers L.M., Feldt-Rasmussen U., Henry J.F., LiVosli V.A., Niccoli-Sire P., John R.,Ruf J., Smyth P.P., Spencer C.A. \& Stockigt J.R. Laboratory medicine practice guidelines. Laboratory support for the diagnosis and monitoring of thyroid disease. Thyroid. 2003;13:3-126.

13. Brabant G., Beck-Peccoz P., Jarzab B., Laurberg P., Orgiazzi J., Szabolcs I., Weetman
A.P. \& Wiersinga W.M. Is there a need to redefine the upper normal limit of TSH? European Journal of Endocrinology. 2006;154:633-7.

14. Tanaka T., Tamai H., Kuma K., Matsuzuka F. \& Hidaka H. Gonadotropin response to luteinizing hormone releasing hormone in hyperthyroid patients with menstrual disturbances. Metabolism. 1981;30:323-6.

15. Goldsmith R.E., Sturgis S.H., Lerman J. \& Stanbury J.B. The menstrual pattern in thyroid disease. Journal of Clinical Endocrinology and Metabolism. 1952;12:846-55.

16. Krassas G.E. Thyroid disease and female reproduction. Fertility and Sterility. 2000;74:106370 .

17. Bjoro T., Holmen J., Kruger O., Midthjell K., Hunstad K., Schreiner T., Sandnes L. \& Brochmann H. Prevalence of thyroid disease, thyroid dysfunction and thyroid peroxidase antibodies in a large, unselected population. The Health Study of Nord-Trondelag (HUNT). European Journal of Endocrinology. 2000;143:639-47.

18. Joshi J.V., Bhandarkar S.D., Chadha M., Balaiah D. \& Shah R. Menstrual irregularities and lactation failure may precede thyroid dysfunction or goitre. Journal of Postgraduate Medicine. 1993;39:137-41.

19. Krassas G.E., Pontikides N., Kaltsas T., Papadopoulou P., Paunkovic J., Paunkovic N. \& Duntas L.H. Disturbances of menstruation in hypothyroidism. Clinical Endocrinology. 1999;50:655-9.

DOI: $10.5455 / 2320-1770 . i j \operatorname{rog} 20140310$

Cite this article as: Gowri M, Radhika BH,

Harshini V, Ramaiaha R. Role of thyroid function tests in women with abnormal uterine bleeding. Int J Reprod Contracept Obstet Gynecol 2014;3:54-7. 